\title{
Forensically Flies Detect the Nutritional Value of Corpses Through Neuro-Chemoreceptive Cells-(5th Cell)
}

\author{
Hedayat Abdel Ghaffar, Tarek Tantawi, \\ Ibrahim Gaboub, Omar Abdel Salam Shalaby and Nagwa El-Refai \\ Department of Zoology, Faculty of Science, Alexandria University, Alexandria, Egypt
}

Received 2012-08-20, Revised 2012-08-29; Accepted 2012-09-04

\begin{abstract}
Animals have evolved several chemosensory systems for detecting potentially dangerous foods in the environment. Activation of specific sensory cells within these chemosensory systems usually elicits an aversive behavioral response, leading to avoidance of the noxious foods. Blowflies respond to sugars, salts and water through the activation of specific chemoreceptor neurons in the antennal, labellar and tarsal chemosensillae. These insects also detect deterrent stimuli with the so called fifth or deterrent cell. Using forensically important flies (blowflies) as a model organism, the question was if these flies have the ability to detect the nutritional value of corpses when injected with different doses of morphine. In the attempt to gain information on the mechanisms underlying reception of noxious and repellent compounds, electrophysiological and behavioral experiments have been performed to confirm the hypothesis that morphine sulfate has a repellent effect on fly attraction to corpse. Electrophysiological and behavioral results indicate that morphine sulfate activate the fifth cell in the chemosensillae. In field behavioral test, carrions injected with doses of morphine sulfate, are colonized later with flies than morphine-free carrions. This finding is in accordance with the spike frequency elevation observed for the fifth cell activity. The prevailing activation of the deterrent cell by morphine sulfate is directly coupled with a coherent behavioral output. Therefore, comparison of behavioral and electrophysiological data, affirm that blowfly identify morphine sulfate as a deterrent stimuli by activation of the fifth cell.
\end{abstract}

Keywords: Blowflies, Electrophysiology, Chemoreceptive Neurons

\section{INTRODUCTION}

Over the last decades interest has increased regarding the identification of Volatile Organic Chemicals (VOCs) for medical, toxicological and environmental applications. While this is still in the early stage of investigations, other areas of research have revealed important findings that could be relevant to forensic entomology (LeBlanc and Logan, 2010). The odor of putrefaction is characteristic and familiar to the front line experts such as police investigators, forensic pathologists, anthropologists, entomologists, crime scene technicians and other medical and non-medical professionals. The chemical analysis of malodours compounds has not attracted much of research interest. It has been referred to that investigators do not attempt to identify and quantitate these compounds because routine methods cannot detect them at their low concentrations. However, these odours are readily sensed by various insects with their sensitive olfaction (Slatheropoulos et al., 2005).

In order to locate the remains, often from long distances, flies are equipped with excellent olfactory organs to detect chemical cues being produced by corpse decomposition (Sukontason et al., 2004), there chemosensory systems detect a wide range of volatile and soluble chemicals and are important for finding and assessing the quality of food sources, in addition to identifying mates and ovipostion sites.

The olfactory and gustatory sensillae of insects are innervated, by four receptor neurons (ORNs and GRNs), all of which are readily accessible for extracellular electrophysiological recording. The spikes recorded from

Corresponding Author: Hedayat Abdel Ghaffar, Department of Zoology, Faculty of Science, Alexandria University, Alexandria, Egypt 
each of the four chemoreceptors consistently differ in amplitude and shape, also their relative amplitude ratios are conserved species and sensillum-type specific, regardless the recording conditions. Three of these sensory cells have been identified as "salt", "sugar" and "water" units depending on their best stimuli (Liscia et al., 2004). In fact, each neuron may be also responsive to other chemicals. As for the remaining chemosensory cell, it was formerly named the "anion" cell, on the basis of a supposed sensitivity to anions or the "5th" cell. More recently, the 5th cell has been shown to respond to deterrent compounds, similarly to the "bitter" cell in vertebrates (Liscia et al., 2004).

Semiochemicals play a considerable role in mediating insect behaviour (Birkett et al., 2004; Pickett et al., 1998). Identifying these specific compounds and investigating the response they elicit, could provide a better understanding of the insects and in some cases, allow manipulation of their behaviour. The period between death and the arrival of the first ovipositing blowflies is of great interest to the forensic entomologist, yet it is not fully understood. To date, entomology still remains the most reliable method of determining the post mortem interval, however, it is anticipated that in the future volatiles associated with a decomposing body, a "chemical fingerprint", which may be used to determine the time of death and provide the pathologist with important forensic details (Vass et al., 2002; Statheropoulos et al., 2007).

Previous researches focused on the growth rates of initial flies that bred on carrion. There has been minimal research looking at the effects of morphine on the attraction of adult fly species to carcasses killed by morphine (Anderson, 1997; 2000). The objective of our study was to compare the time of arrival of adult fly species attracted to exposed rabbit carcasses killed by different doses of morphine sulfate as well as identifying the chemoreceptive neuron responsible for deterrent responses, under environmental conditions common to an urban area in Alexandria.

\section{MATERIALS AND METHODS}

Studies on rabbit carrion decomposition and its associated insects were conducted in the botanical garden of the Faculty of Science. The study site was located in Moharrem Bey District, which is one of the most highly populated urban areas of Alexandria.

\subsection{Behavioral Experiments}

Three rabbits (Oryctolagus cuniculus L.) were used for each seasonal experiment (summer and winter), two of which received 12.5 and $25 \mathrm{mg} \mathrm{Kg}^{-1}$ of morphine sulfate, diluted in $10 \mathrm{~mL}$ normal saline via cardiac puncture. These dosages were calculated to obtain morphine tissue concentrations similar to those encountered in fatal human overdoses (Hedouin et al., 1999). The third rabbit was used as a control and received only $10 \mathrm{~mL}$ normal saline. Rabbits were killed by strangulation, $30 \mathrm{sec}$ following drug administration.

The carcasses were inspected twice daily areas of insect activity and records of the arrival, departure and abundance of the adult blowflies; Lucilia serciata, Chrysomya albiceps and Calliphora vicina were recorded.

\subsection{Neuro-Electrophysiological Experiments}

Intact puparia of Calliphora vicina, Chrysomya albiceps and lucilia sericata, which were collected from underneath the carcasses of the control and treated $(0.5$ $\mathrm{LD}_{50}$ and $\mathrm{LD}_{50}$ ), were separately placed in jars with wet sawdust and covered with a fine mesh cloth secured with rubber bands. Water was only introduced to flies for 36-48 h. Fifteen flies of each species were anaesthetized by chilling in a refrigerator for approximately ten minutes. Each fly was then strapped, onto a specially constructed block of balsa wood, with its head at the level of the top of the block by means of a thin strip of sticky dental wax placed across the back of the fly. The proboscis was held in an extended position on top of the block using a metal staple formed from a minute pin, (Wasserman and Itagaki, 2003).

The impulses of neural responses of antennal, labellar and tarsal chemosensilla were recorded using the non invasive extracellular tip recording technique of Hodgson et al. (1955) (Fig. 1). A glass electrode with a diameter of $40 \mu \mathrm{m}$ at the tip, containing morphine sulfate dissolved in $0.1 \mathrm{M} \mathrm{NaCl}$ to maintain electrical conductance, was placed over the tip of a chemosensillum. Excitatory responses of chemosensory cells within the sensillum were recorded (Glendinning et al., 2001). A thin silver wire coated with $\mathrm{AgCl}$ wire $(\mathrm{Ag} / \mathrm{AgCl}$ wire) serving as a ground electrode was inserted into the dorsal side of the thorax to avoid injuring the inner organs (Liscia and Solari, 2000; Liscia et al., 2004). The stimulating/recording electrode was connected to the input of a standard high impedance DC amplifier with an $\mathrm{Ag} / \mathrm{AgCl}$ wire. Spike discharges were monitored on a Cambridge Electronic Design (CED) 1401 A/D converter and recorded on a magnetic tape through a band-pass filter $(10-1000 \mathrm{~Hz})$. These spikes were digitized and stored on compact disk for further computer analysis (Liscia and Solari, 2000; Liscia et al., 2004).

For each neural recording, the stimulation of each sensillum lasted for $2000 \mathrm{~ms}$ the number of action potentials generated for $0-1000 \mathrm{~ms}$ after contact were quantified. 


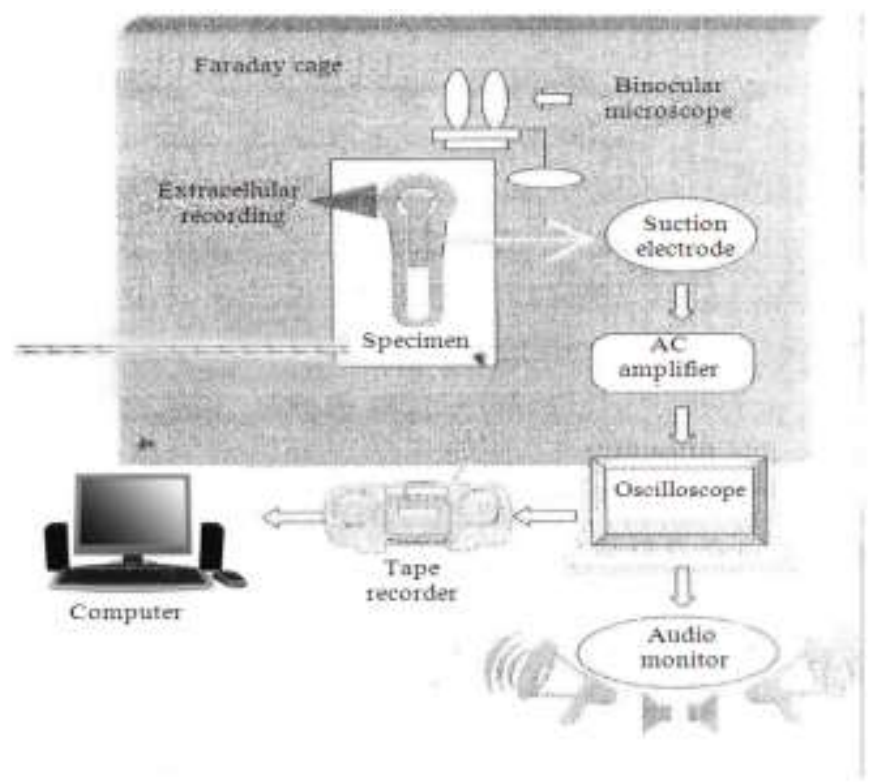

Fig. 1. Electrophysiological recording setup

The interval between each 2 successive stimulation lasted for at least $3 \mathrm{~min}$ three replicates were conducted for each stimulation. Each chemosensilla contains three to four chemoreceptive neurons and each neuron within exhibits a typical amplitude and pattern of firing (Glendinning et al., 1999; 2000). The identification of "salt", "water" and "fifth" cells, were used here in as the basis for discriminating action potentials from different neurons following the response features to pure salt and sugars solutions described and identified as such by (Dethier and Hanson, 1968; Dethier and Bowdan, 1992; Glendinning et al., 2001; Liscia et al., 1997; 1998; Liscia and Solari, 2000).

\section{RESULTS}

\subsection{Field Behavioral Experiments}

During the present study, Lucilia serciata, Chrysomya albiceps and Calliphora vicina, were the initial flies bred in carrions.

The arrival of adults of L. sericata and Chrysomya albiceps at carcasses killed by $0.5 \mathrm{LD}_{50}$ and $\mathrm{LD}_{50}$ of morphine sulfate during summer were delayed by $24 \mathrm{~h}$ compared to their arrival at the control carcass. While the results obtained for the arrival of the fly Calliphora vicina during winter at carcasses were delayed by 4-14 days at dose response to $0.5 \mathrm{LD}_{50}$ and $\mathrm{LD}_{50}$ of morphine, respectively (Fig. 2).

\subsection{Neuro-Electrophysiological Experiments}

Figure 3 shows the different types of chemoreceptive neurons in a sample spike discharges. By comparing the spike shapes and amplitudes to those obtained in response to pure $\mathrm{NaCl}$, these cell types were identified as "salt" (cell 1), "water" (cell 3) and "5th cell" (cell 5) (Dethier 1976; Liscia et al., 2004; Masala et al., 2008). Since the " 5 th" cell is activated by chemicals known to have deterring effects, it is hereafter, referred to as "deterrent" cell (Liscia and Solari, 2000). It is possible to observe that each cell forms its own characteristic shape and amplitude, thus it can be distinguished from the other cells.

\subsection{Effect of Morphine Sulfate Chemoreception of Lucilia Sericata}

Figure 4 shows gustatory responses of labellar chemoreceptive neurons to stimulation with $10 \mathrm{mM} \mathrm{NaCl}$ elicited activites in the salt cell $(1.1 \pm 0.12 \mathrm{imp} / \mathrm{s})$, the 5 th cell $(1.57 \pm 0.16 \mathrm{imp} / \mathrm{s})$ and the water cell $(3.1 \pm 0.34 \mathrm{imp} / \mathrm{s})$. Mixtures of saline and 0.5 LD50 of morphine sulfate elicited a higher firing rate of the $5^{\text {th }}$ cell to $(1.88 \pm 0.024$ $\mathrm{imp} / \mathrm{s})$. The water and the salt cells showed no significance differences in response $(3.13 \pm 0.06 \mathrm{imp} / \mathrm{s} ; 1.15 \pm 0.014$ $\mathrm{imp} / \mathrm{s}$, respectively) compared to saline. Increasing the concentration of morphine to $\mathrm{LD}_{50}$ evoked lower response in the 5 th and the water cells $(1.79 \pm 0.025 \mathrm{imp} / \mathrm{s}$; $2.89 \pm 0.025 \mathrm{imp} / \mathrm{s}$, respectively), while the mean firing frequency of the salt cell increased to $1.3 \pm 0.02 \mathrm{imp} / \mathrm{s}$. 


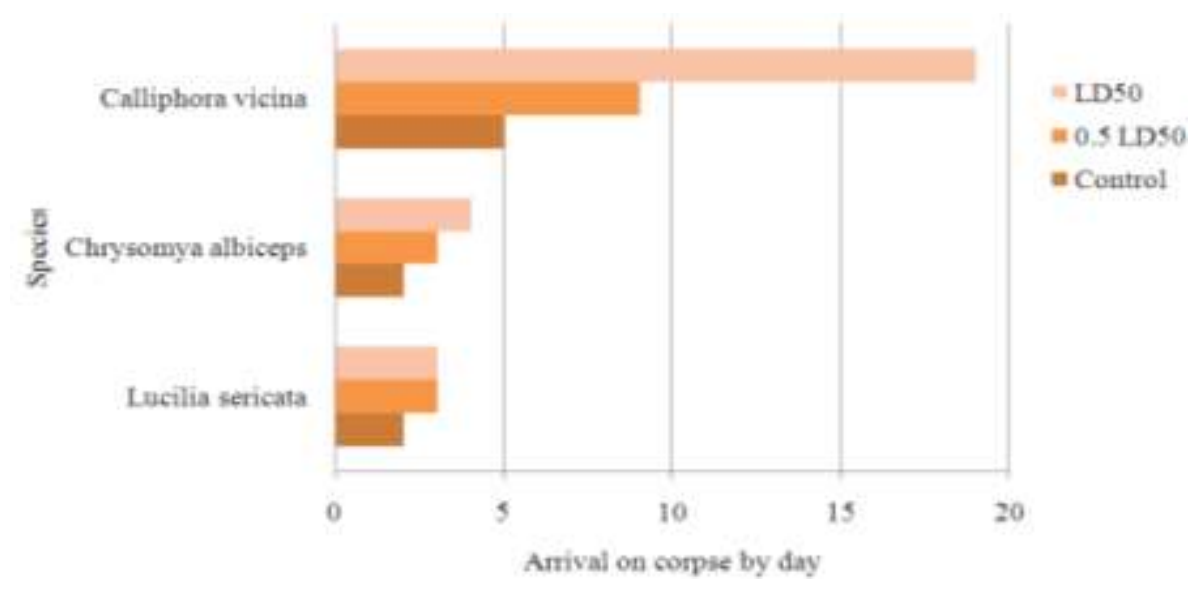

Fig. 2. Effect of morphine on the arrival of adults flies on exposed rabbit carcasses

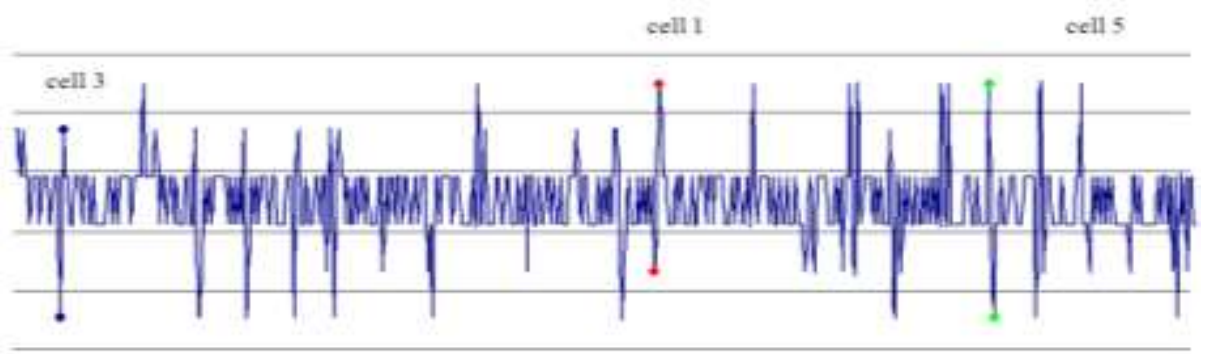

Fig. 3. Sample of spikes discharges of the "salt" (cell 1), "water" (cell 3) and "5th or deterrent" (cell 5) chemosensory neurons

Similarly, three different olfactory cells were also activated in antennal chemosensilla in response to stimulation with $10 \mathrm{mM} \mathrm{NaCl}$ elicited responses from the salt, 5th and water cell $(1.0 \pm 0.04 \mathrm{imp} / \mathrm{s} ; 1.9 \pm 0.04$ $\mathrm{imp} / \mathrm{s} ; 3.4 \pm 0.02 \mathrm{imp} / \mathrm{s}$, respectively). $0.5 \mathrm{LD}_{50}$ of morphine elicited a higher response of the salt cell $(1.3 \pm 0.02 \mathrm{imp} / \mathrm{s})$, while the mean firing frequency was insignificantly affected both to water and 5th cell. Increasing the concentration of morphine to $\mathrm{LD}_{50}$ elicited a lower activity to the salt and the $5^{\text {th }}$ cell $(1.28 \pm 0.04 \mathrm{imp} / \mathrm{s} ; 1.7 \pm 0.02 \mathrm{imp} / \mathrm{s}$, respectively) as compared to $0.5 \mathrm{LD}_{50}$ of morphine, however increasing the morphine concentration showed no effect for the response on the water cell (Fig. 4).

Responses of tarsal gustatory chemoreceptive neurons to $10 \mathrm{mM} \mathrm{NaCl}$ activated the action potentials of the salt, 5 th and wa ter cells $(1.4 \pm 0.08 \mathrm{imp} / \mathrm{s}$; $1.2 \pm 0.04 \mathrm{imp} / \mathrm{s} ; \quad 2.3 \pm 0.08 \mathrm{imp} / \mathrm{s}$ ), respectively. Mixtures of saline and $0.5 \mathrm{LD}_{50}$ of morphine sulfate increased the firing rate of the three cells $(1.8 \pm 0.032$ $\mathrm{imp} / \mathrm{s} ; 1.8 \pm 0.048 \mathrm{imp} / \mathrm{s} ; 3.6 \pm 0.052 \mathrm{imp} / \mathrm{s})$, respectively. $\mathrm{LD}_{50}$ of morphine evoked a higher response to the three cells $(3.75 \pm 0.046 \mathrm{imp} / \mathrm{s} ; 2.9 \pm 0.026 \mathrm{imp} / \mathrm{s} ; 4.2 \pm 0.048$ $\mathrm{imp} / \mathrm{s}$ ), respectively (Fig. 4).

\subsection{Effect of Morphine Sulfate on chemoreception of Chrysomya Albiceps}

Stimulation with $10 \mathrm{mM} \mathrm{NaCl}$, elicited response through three chemoreceptive neurons of the labellar chemosensilla, producing spikes in the salt cell $(1.38 \pm 0.13 \mathrm{imp} / \mathrm{s})$, the 5 th cell $(1.88 \pm 0.32 \mathrm{imp} / \mathrm{s})$ and the water cell $(3.54 \pm 0.76 \mathrm{imp} / \mathrm{s})$. As shown by the histogram in Fig. 1, morphine evoked, as expected, a major response from the "deterrent cell" when compared to the response of pure saline. The spike firing frequency to $\mathrm{LD}_{50}$ morphine $(3.7 \pm 0.16 \mathrm{imp} / \mathrm{s})$ being higher than that of $0.5 \mathrm{LD}_{50}(1.9 \pm 0.11 \mathrm{imp} / \mathrm{s})$, thus indicating to dose response relationship, in which the firing activity of the deterrent cell increases by increasing the concentration of morphine. Results in Fig. 5, show that, the stimulation of both salt and water cells with low concentration of morphine $(0.5$ $\left.\mathrm{LD}_{50}\right)$ decrease their firing activity $(1.16 \pm 0.07 \mathrm{imp} / \mathrm{s}$; $2.3 \pm 0.35 \mathrm{imp} / \mathrm{s}$, respectively) while higher concentration of morphine $\left(\mathrm{LD}_{50}\right)$ enhances their activity $(2.34 \pm 0.26 \mathrm{imp} / \mathrm{s}$; $4.15 \pm 0.15 \mathrm{imp} / \mathrm{s}$, respectively) (Fig. 5). 
Typically in the antennal chemosensilla stimulated with $10 \mathrm{mM} \mathrm{NaCl}$ elicited responses in the salt cell $(1.2 \pm 0.31 \mathrm{imp} / \mathrm{s})$, the 5 th cell $(2.2 \pm 0.66 \mathrm{imp} / \mathrm{s})$ and the water cell $(3.3 \pm 0.18 \mathrm{imp} / \mathrm{s})$. Mixture of saline and 0.5 $\mathrm{LD}_{50}$ of morphine sulfate elicited a lower firing activity in the $5^{\text {th }}$ and water cells $(1.74 \pm 0.15 \mathrm{imp} / \mathrm{s} ; 3.1 \pm 0.20$ $\mathrm{imp} / \mathrm{s}$, respectively). The mean rate of firing activity of the salt cell was significantly higher than that of the pure saline (1.35 \pm 0.18$)$. Increasing morphine concentration $\left(\mathrm{LD}_{50}\right)$ increased the firing rate of the $5^{\text {th }}$ cell $(3.1 \pm 0.54 \mathrm{imp} / \mathrm{s})$, salt cell $(2.24 \pm 0.8 \mathrm{imp} / \mathrm{s})$ and water cell $(4.0 \pm 0.95 \mathrm{imp} / \mathrm{s})($ Fig. 5).
Responses of tarsal chemoreceptive neurons to $10 \mathrm{mM} \mathrm{NaCl}$ activated action potentials of the salt, $5^{\text {th }}$ and water cells $(1.2 \pm 0.31 \mathrm{imp} / \mathrm{s} ; 2.2 \pm 0.66 \mathrm{imp} / \mathrm{s}$; $3.3 \pm 0.18 \mathrm{imp} / \mathrm{s}$, respectively). Mixtures of saline and 0.5 $\mathrm{LD}_{50}$ of morphine sulfate elicited a higher firing rate of the salt cell to $(1.35 \pm 0.18 \mathrm{imp} / \mathrm{s})$ and a lower firing activity of both the 5 th and water cells $(1.74 \pm 0.15 \mathrm{imp} / \mathrm{s}$; $3.1 \pm 0.20 \mathrm{imp} / \mathrm{s}$, respectively). Increasing the concentration of morphine to $\mathrm{LD}_{50}$ evoked higher response for the three cells $(2.24 \pm 0.8 \mathrm{imp} / \mathrm{s}$; $3.1 \pm 0.54 \mathrm{imp} / \mathrm{s} ; 4.0 \pm 0.95 \mathrm{imp} / \mathrm{s}$, respectively), showed a clear dose response relationship (Fig. 5).

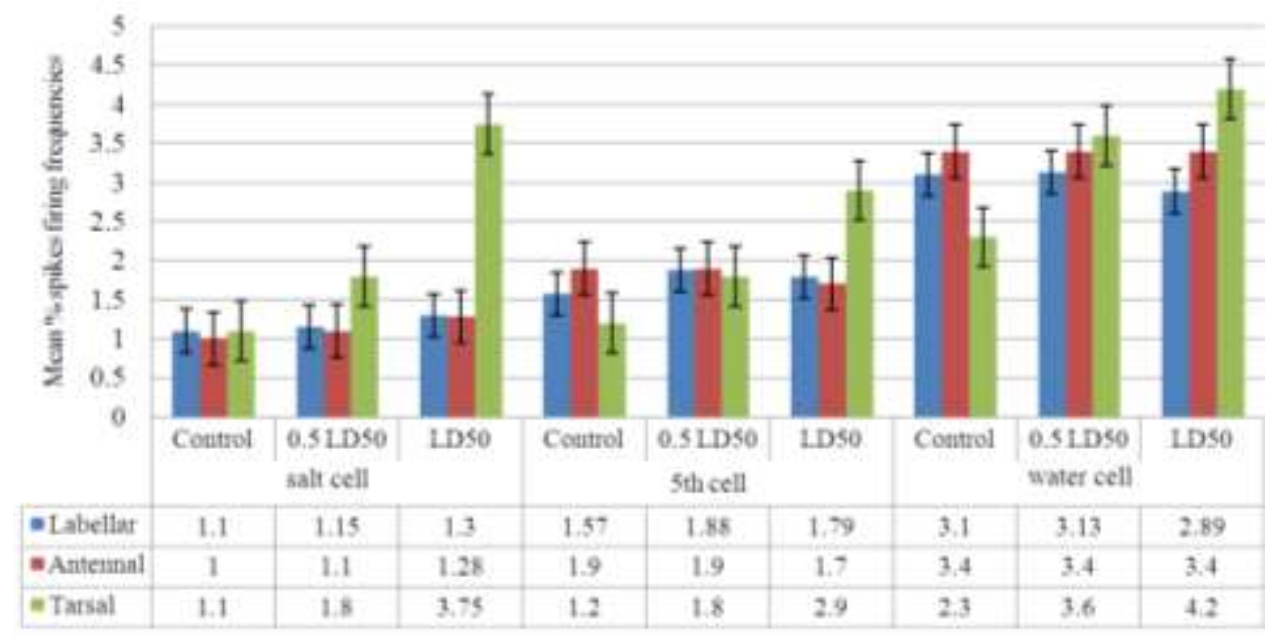

Fig. 4. Spike firing frequency (spike/s) recorded from Lucilia sericata in response to $10 \mathrm{Mm}$ saline and doses of morphine sulfate (0.5LD50 and LD50), vertical bars (Mean \pm standard error)

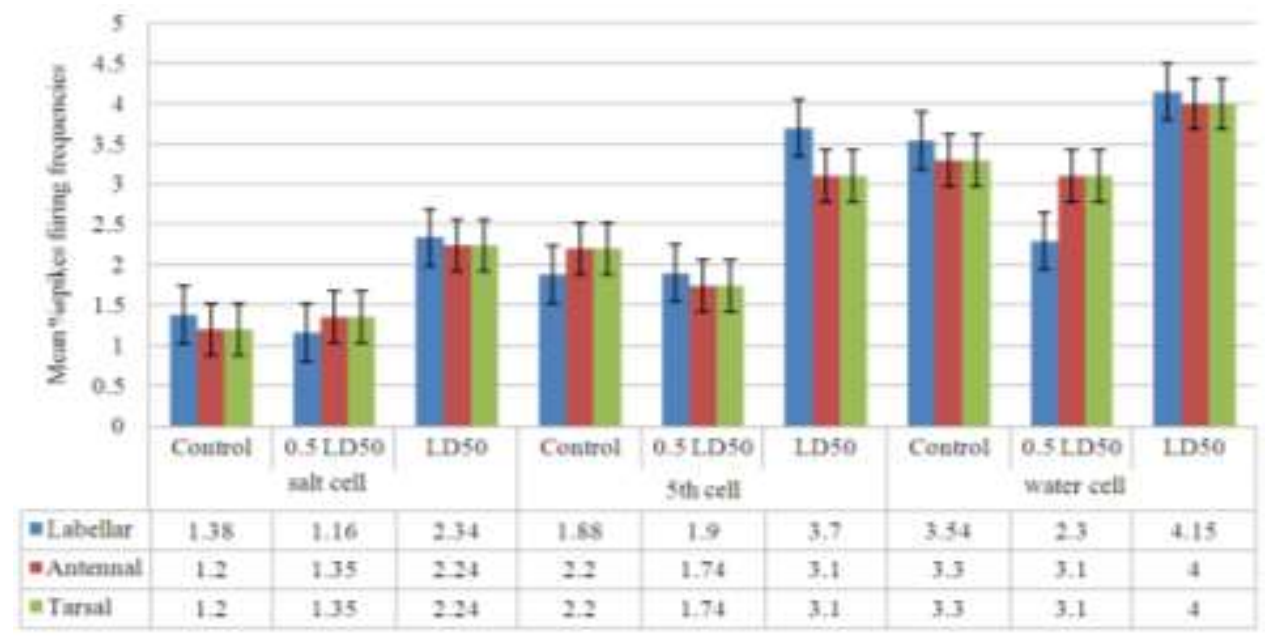

Fig. 5. Spike firing frequency (spike/s) recorded from Chrysomya albiceps in response to $10 \mathrm{Mm}$ saline and doses of morphine sulfate (0.5 LD50 and LD50), Vertical bars (mean \pm standard error 


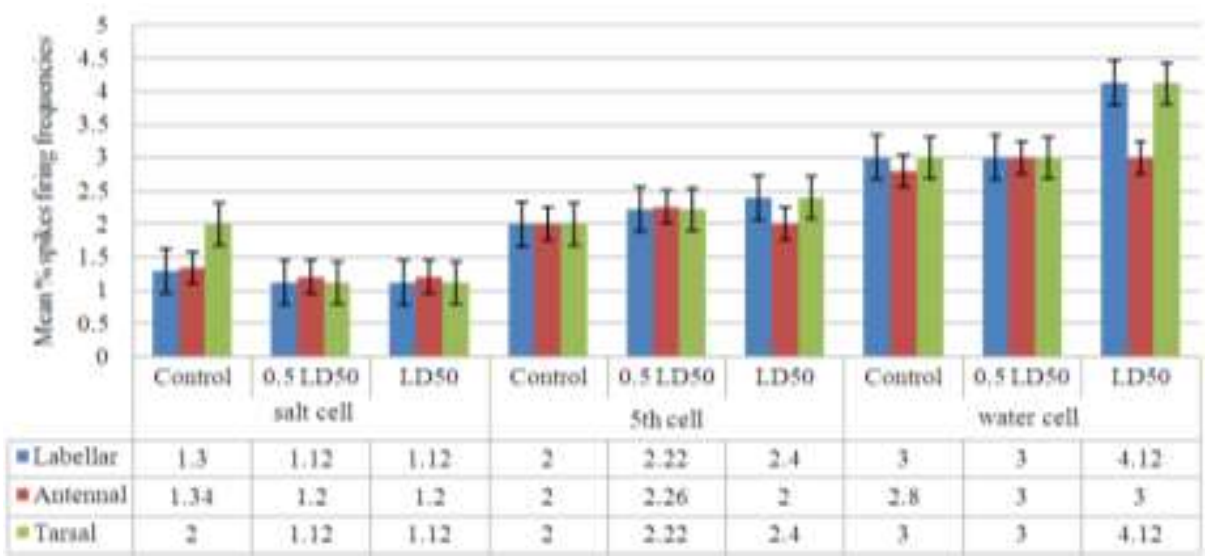

Fig. 6. Spike firing frequency (spike/s) recorded from Calliphora vicina in response to $10 \mathrm{Mm}$. saline and doses of morphine sulfate $(0.5$ LD50 and LD50), Vertical bars (mean \pm standard error)

\subsection{Effect of Morphine Sulfate on Chemoreception of Calliphora Vicina}

In response to $10 \mathrm{mM} \mathrm{NaCl}$, the three chemoreceptive neurons were fired, producing spikes in the salt cell $(1.3 \pm 0.036 \mathrm{imp} / \mathrm{s})$, the 5th cell $(2.0 \pm 0.046 \mathrm{imp} / \mathrm{s})$ and the water cell $(3.0 \pm 0.042$ $\mathrm{imp} / \mathrm{s})$. Mixtures of saline and $0.5 \mathrm{LD}_{50}$ of morphine sulfate increased the firing activity of the 5th cell to $(2.22 \pm 0.054 \mathrm{imp} / \mathrm{s})$, while the firing rate of the salt cell decreased to $(1.12 \pm 0.026 \mathrm{imp} / \mathrm{s})$. The water cell showed no differences in response when compared to saline.

Increasing the concentration of morphine to $\mathrm{LD}_{50}$ evoked higher response in the 5th and the water cells (2.4 $\pm 0.032 \mathrm{imp} / \mathrm{s} ; 4.12 \pm 0.046 \mathrm{imp} / \mathrm{s}$, respectively), however increasing morphine concentration showed no effect on the response of the salt cell (Fig. 6).

Typically stimulus of $10 \mathrm{mM} \mathrm{NaCl}$ elicited responses in the salt cell $(1.34 \pm 0.023 \mathrm{imp} / \mathrm{s})$, the 5 th cell $(2.0 \pm 0.028$ $\mathrm{imp} / \mathrm{s})$ and the water cell $(2.8 \pm 0.054 \mathrm{imp} / \mathrm{s})$. Mixture of saline and $0.5 \mathrm{LD}_{50}$ of morphine sulfate elicited a higher firing activity in the 5th and water cells $(2.26 \pm 0.044$ $\mathrm{imp} / \mathrm{s} ; 3.0 \pm 0.086 \mathrm{imp} / \mathrm{s}$, respectively). The mean rate of firing activity of the salt cell was significantly lower than that of the pure saline $(1.2 \pm 0.023 \mathrm{imp} / \mathrm{s})$. increasing morphine concentration ( $\left.\mathrm{LD}_{50}\right)$ decreased the firing rate of the 5 th cell $(2.0 \pm 0.089 \mathrm{imp} / \mathrm{s})$, while the salt and water cells showed no difference in response, compared with response to $0.5 \mathrm{LD}_{50}$ of morphine (Fig. 6).

Responses of tarsal chemoreceptive neurons to $10 \mathrm{mM}$ $\mathrm{NaCl}$ activated action potentials of salt, 5th and water cells (1.3 $\pm 0.036 \mathrm{imp} / \mathrm{s} ; 2.0 \pm 0.046 \mathrm{imp} / \mathrm{s} ; 3.0 \pm 0.042 \mathrm{imp} / \mathrm{s}$, respectively). Mixtures of saline and $0.5 \mathrm{LD}_{50}$ of morphine sulfate elicited a higher firing rate of the 5th cell to
$(2.22 \pm 0.054 \mathrm{imp} / \mathrm{s})$, while the mean spikes firing frequency of the salt cell was decreased to $(1.12 \pm 0.026$ $\mathrm{imp} / \mathrm{s})$. The water cell showed no differences in response compared to the response to saline. Increasing the concentration of morphine to $\mathrm{LD}_{50}$ evoked higher response in the 5 th and the water cells $(2.4 \pm 0.032 \mathrm{imp} / \mathrm{s}$; $4.12 \pm 0.046 \mathrm{imp} / \mathrm{s}$, respectively); however the effect on the salt cell was insignificant (Fig. 6).

\section{DISCUSSION}

The sense of olfaction or taste in insects is categorized into four functionally differentiated receptor cells. Only four chemosensory neurons are present in each chemosensillum, it could be excluded that different bitter or deterrent stimuli may activate different subpopulations of sensitive cells, as reported by Caicedo and Roper (2001) in vertebrates. The effect of the activity of the 5th cell in flies behavior is a quest. Prior to the present study, Liscia and Solari (2000) reported that the $5^{\text {th }}$ cell of $\mathrm{P}$. terraenovae responded to some substances that humans find bitter. In addition to the electrophysiological results, they showed that the fly preferred pure sucrose solution to mixtures of sucrose plus quinine or amiloride. These results might easily lead to the conclusion that the $5^{\text {th }}$ cell of the fly has a functional analogy to the bitter taste receptor cell of humans, although all substances being bitter for humans or other mammals may not be recognized as deterrents in insects (Liscia and Solari, 2000; Ozaki et al., 2003). In fact, the 5th cell responds to quite different structures of molecules which have not been investigated in details. This is one of the main reasons why the fifth cell has not been given a name according to its function. Considering the study of Liscia and Solari (2000), however this cell can be defined as a deterrent cell 
The results herein are in agreement with those of Dethier (1976) who observed that at low concentration of $\mathrm{NaCl}$ only one cell in a hair is stimulated, the water cell. Over the middle range of concentrations three cells respond, one of these is the water cell and the other two are salt receptors. At the upper end of concentration of $\mathrm{NaCl}$, presumably the water cell, drops out and the other two continues to respond. None of the cells was the sugar receptor. In the light of this fact and by comparing the spike shapes and amplitudes in this study to those obtained in response to pure $\mathrm{NaCl}$ (Liscia et al., 2004; Masala et al., 2008), it was then assumed that these cell types were identified as "salt", "water" and " 5 th cell".

The present study was aimed to asses a suggestion that morphine sulfate modulates the peripheral chemosensory apparatus responsiveness in the flies by enhancing the activity of the $5^{\text {th }}$ cell. This goal has been achieved by analyzing the electrophysiological responses of the labellar, antennal and tarsal chemosensillae to a complex stimulus of $\mathrm{NaCl}$ and different doses of morphine sulfate $\left(0.5 \mathrm{LD}_{50}\right.$ and $\left.\mathrm{LD}_{50}\right)$.

Within the time frame of our experiment, in most records a positive dose response was observed in which, the firing activity of the deterrent cell increases by increasing the concentration of morphine, this is accompanied by a significant decrease in the activity of the salt cell. Seemingly, the direct stimulation effect exerted by morphine on the 5th cell adds up to the inhibitory effect on the salt cell to provide a stronger deterrence signal to the central nervous system. A similar phenomenon has also been described for quinine in the hamster nucleus of the solitary tract ( $\mathrm{Li}$ and Smith, 1996).

As performed in this study, the data obtained through the field experiments, flies delayed significantly in colonizing carrions injected with morphine. Tahis finding is in accordance with respect to the spike frequency elevation observed for the 5th cell activity, however it was not the case for the responses of the antennal chemosensilla of Chr. albiceps, L. sericata and C. vicina. In order to explain, partly at least, the lack of agreement between the depression of what is believed to be the deterrent cell and its expected behavioral program (rejection), we should recall what Dethier (1976) wrote in this respect: "Behavioral and electrophysiological studies also pointed to multiple modes of action resulting in behavioural rejection". Such studies showed that compounds may stimulate the salt receptor, they may stimulate the 5th cell and they can cause complex inhibitory interactions. In this respect herein, the implication is that fly can differentiate among various kinds of unacceptable materials and may behave in a significant different manner towards each. Interestingly, there was a possibility then that its chemoreceptive world might not be simply a matter of the "acceptable" and "unacceptable" but might involve many more subtle taste and/or olfactory distinctions (Liscia et al., 2004).

There is a vast body work supporting the role of osmometer for the water cell (Evans and Mellon 1962a; 1962b; Rees, 1970; 1972), in this respect, one would expect an inverse dose response relationship by increasing solute concentration that means the water cell firing activity decreases by increasing morphine concentration. In accordance to this, the results obtained herein are not in consistent with dose-response for the water cell, is considered as an osmometer. To explain this lack of agreement, one should recall that this cell is known to respond to other compounds (Wieczorek and Koppl, 1978). Liscia and Solari (2000) found that the spike activity of the water cell evoked by $\mathrm{NaCl}$ appears to be enhanced by $\mathrm{W}-7$ in a concentration dependent manner and in agreement with the hypothesis that the water cell be a multirole receptor (Wieczorek and Koppl, 1978). Thus the role of water cell in relation to morphine responsiveness needs further investigations.

\section{CONCLUSION}

Our results conclusively support the hypothesis that morphine acts at the peripheral level by modulating labellar, antennal and tarsal responsiveness. In this respect, morphine was found to enhance the "deterrent" cell responsiveness also reduce the firing activity of the salt cell. On the basis of these results, morphine seems to be a candidate as a neuroeffector involved in the modulation of the "deterrent" cell sensitivity.

\section{REFERENCES}

Anderson, G.S., 1997. The use of insects to determine time of decapitation: A case-study from British Columbia. J. Forensic Sci., 42: 947-950. PMID: 9304851

Anderson, G.S., 2000. Minimum and maximum development rates of some forensically important Calliphoridae (Diptera). J. Forensic Sci., 45: 824832. PMID: 10914578

Birkett, M.A., N. Angelopoulos, K.M.V. Jensen, J.B. Jespersen and J.A. Pickett et al., 2004. The role of volatile semiochemicals in mediating host location and selection by nuisance and disease-transmitting cattle flies. Med. Vet. Entomol., 18: 313-322. PMID: 15641996

Caicedo, A. and S.D. Roper, 2001. Taste receptor cells that discriminate between bitter stimuli. Science, 291: 1557-1560. PMID: 11222863

Dethier, V.G. and E. Bowdan, 1992. Effects of alkaloids on feeding by Phormia reginaconfirm the critical role of sensory inhibition. Physiol Entomol., 17: 325-330. DOI: 10.1111/j.1365-3032.1992.tb01030.x 
Dethier, V.G. and F.E. Hanson, 1968. Electrophysiological responses of the chemoreceptors of the blowfly to sodium salts of fatty acids. Proc. Natl. Acad. Sci. USA., 60: 1269-1303.

Dethier, V.G., 1976. The Hungry Fly: A Physiological Study of the Behavior Associated with Feeding. 1st Edn., Harvard University Press, Cambridge, ISBN10: 0674427106, pp: 489.

Evans, D.R. and D.F. Mellon, 1962a. Electrophysiological studies of a water receptor associated with taste sensilla of blow-fly. J. Gen. Physiol., 45: 487-500. PMID: 13890971

Evans, D.R. and D.F. Mellon, 1962b. Stimulation of a primary taste receptor by salt. J. Gen. Physiol., 45: 651-661.

Glendinning, J.I., H. Brown, M. Capoor, A. Davis and A. Gbedemah et al., 2001. A peripheral mechanism for behavioral adaptation to specific "Bitter" taste stimuli in an insect. J. Neurosci., 21: 3688-3696.

Glendinning, J.I., M. Tarre and K. Asaoka, 1999. Contribution of different bitter-sensitive taste cells to feeding inhibition in a caterpillar. Behav Neurosci., 113: 840-854. PMID: 10495092

Glendinning, J.L., N. Nelson and E.A. Bernays, 2000. How do inositol and glucose modulate feeding in Manduca sexta caterpillar. J. Exp. Biol., 203: 12991315. PMID: 10729279

Hedouin, V., B. Bourel, L. Martin-Bouyer, A. Becart and G. Tournel et al., 1999. Morphine perfused rabbits: A tool for experiments in forensic entomotoxicology. J Forensic Sci., 44: 347-350. PMID: 10097360

Hodgson, E.S., J.Y. Lettvin and K.D. Roeder, 1955. Physiology of a primary chemoreceptor unit. Science, 122: 417-418. PMID: 13246649

LeBlanc, H.N. and J.G. Logan, 2010. Exploiting insect olfaction in forensic entomology. Curr. Concepts Forensic Entomol. DOI: 10.1007/978-1-4020-9684-6_11

Li, C.S. and D.V. Smith, 1996. Mutual inhibition between sucrose and quinine or denatonium in cells of the hamster solitary nucleus. Chem Senses, 21: 632-632.

Liscia, A. and P. Solari, 2000. Bitter taste recognition in the blowfly: Electrophysiological and behavioral evidence. Physiol. Behav., 70: 61-65. PMID: 10978479

Liscia, A., C. Masala, R. Crnjar, G. Sollai and P. Solari, 2004. Saccharin stimulates the "deterrent" cell in the blowfly: Behavioral and electrophysiological evidence. Physiol. Behav., 80: 637-646. PMID: 14984797

Liscia, A., P. Solari, R. Majone and R. Crnjar, 1998. Amiloride high-and low-sensitivity, as well as insensitive sites in the blowfly: Implications for sugar, water and anion taste reception mechanisms. Primary Sensory Neuron., 3: 49-59.
Liscia, A., P. Solari, R. Majone, B.I. Tomassini and R. Crnjar, 1997. Taste reception mechanism in the blowfly: Evidence of amiloride-sensitive and insensitive receptor sites. Physiol. Behav., 62: 875789. PMID: 9284511

Masala, C., P. Solari, G. Sollai, R. Crnjar and A. Liscia, 2008. Clonidine effects on protein and carbohydrate electrophysiological responses of labellar and tarsal sensilla in Phormia regina. J. Insect. Physiol., 54: 1193-1199. PMID: 18634799

Ozaki, M., T. Takahara, Y. Kawahara, A. WadaKastumata and K. Seno et al., 2003. Perception of noxious compounds by contact chemoreceptors of the blowfly, Phormia regina: Putative role of an odorant-bindingpProtein. Chem. Senses, 28: 349359. PMID: 12771021

Pickett, J.A., L.J. Wadhams and C.M. Woodcock, 1998. Insect supersense: Mate and host location by insects as model systems for exploiting olfactory interactions. Biochemistry, 20: 8-13.

Rees, C.J.C., 1970. The primary process of reception in the type 3 ("water") receptor cell of the fly Protophormia terranova. Proc. R Soc. Lond. B., 174: 469-469.

Rees, C.J.C., 1972. Responses of same sensory cells probably associated with the detection of water. Proceedings of the 4th International Symposium of Olfaction and Taste (OT' 72) Wiss, Verlagsges, Stuttgart, pp: 88-94.

Slatheropoulos, M., C. Spiliopoulou and A. Agapiou, 2005. Study of volatile organic compounds evolved from the decaying human body. Forensic Sci. Int., 153: 147-155. PMID: 16139103

Statheropoulos, M., A. Agapiou, C. Spiliopoulou, G.C. Pallis and E. Sianos, 2007. Environmental aspects of VOCs evolved in the early stages of human decomposition. Sci. Total Environ., 385: 221-227. PMID: 17669473

Sukontason, K., K.L. Sukontason, S. Piangjai, N. Boonchu and T. Chaiwong et al., 2004. Antennal sensilla of some forensically important flies in families Calliphoridae, Sarcophagidae and Muscidae. Micron, 35: 671-679. PMID: 15288645

Vass, A.A., S.A. Barshick, G. Sega, J. Caton and J.T. Skeet et al., 2002. Decomposition chemistry of human remains: A new methodology for determining the postmortem interval. J. Forensic Sci., 47: 542-553. PMID: 12051334

Wasserman, S.L. and H. Itagaki, 2003. The olfactory responses of the antenna and maxillary palp of the fleshfly, Neobellieria bullata (Diptera: Sarcophagidae) and their sensitivity to blockage of nitric oxide synthase. J. Insect Physiol., 49: 271280. PMID: 12770002

Wieczorek, H. and R. Koppl, 1978. Effect of sugars on the labellar water receptor of the fly. J. Compt. Physiol. A, 126: 131-136. DOI: 10.1007/BF00666365 